\title{
Effects of Film Mulching on Aroma Components of Pineapple Fruits
}

\author{
Chuanhe Liu, Yan Liu \& Ganjun Yi \\ Institute of Fruit Tree Research, Guangdong Academy of Agricultural Sciences \\ Guangzhou 510640, Guangdong, China \\ E-mail: founderlch@126.com
}

Meijing Liao, Yanzhou Wu, Fengling Wei \& Shunqiu Zhu

Centre of Agricultural Technology Extension of Zengcheng City

Guangzhou 511300, Guangdong, China

Received: November 15, 2010 Accepted: November 30, 2010 doi:10.5539/jas.v3n3p196

\begin{abstract}
The aim of this study was to test the effects of film mulching treatment on aroma components of pineapple fruits. In this present study, the pineapple fruits of treatment and control (open field) were harvested twice (in winter and summer, respectively) to detect the aroma components. The results indicated that esters and alkenes were the main aroma components of both treatment and control pineapple fruits. There were more kinds of esters with higher total relative contents detected in the treatment fruits both harvested in winter and summer. There were fewer kinds of alkenes with lower total relative contents detected in the treatment fruits harvested in summer. There were equal kinds of alkenes detected in both treatment and control fruits harvested in winter. But the total relative content of alkenes of treatment fruits harvested in winter was lower than that of control. There was one ester containing sulfur, propanoic acid, 3-(methylthio)-, methyl ester with relative content of $1.40 \%$, detected in the treatment fruits harvested in winter. No ester containing sulfur was detected in the control fruits harvested in winter. In the treatment fruits harvested in summer, two esters containing sulfur, propanoic acid, 3-(methylthio)-, methyl ester $(2.60 \%)$ and 3-(methylthio) propanoic acid ethyl ester $(1.46 \%)$ were detected. There was only one ester containing sulfur, propanoic acid, 3-(methylthio)-, methyl ester $(3.01 \%)$ was detected in the control fruits harvested in summer.
\end{abstract}

Keywords: Pineapple, Film mulching, Aroma components

\section{Introduction}

Pineapple [Ananas comosus (L.) Merr.], cultivated worldwide all around the tropical and subtropical regions for local consumption and international export, is the most important representative of the Bromeliaceae family. The pineapple fruit is consumed freshly by many people and used as source of essential mineral elements, nutrients and vitamins. Pineapple is an important fresh fruit, which is widely cultivated in a few provinces of southern China. According to the newly online databases from Ministry of Agriculture of P. R. China, China is one of the leading producers of pineapple with area 53500 ha and yields $933633 \mathrm{t}$ in 2008. However, in most pineapple production areas of China, the growth of pineapple plant is retarded due to the seasonal drought and shortage of water during autumn-winter-spring seasons.

Film mulching is an important practice which is wildly used in crop production. Film mulching can modify the microclimate, reduce water evaporation from soil, and maintain the soil humidity (Tarara, 2000; Bu et al., 2006; Zhang et al., 2010). Historically, vegetable growers have employed plastic films for mulching to reduce the growth of weeds, soil erosion from wind or water, leaching of fertilizers, especially on light, sandy soils, and the development of plant diseases coming from the soil. Black polyethylene is the most widely used due to its excellent properties and low cost. It can improve the farming soil temperature, activate the soil nutrition and increase the nutrient availability of soil (Li et al., 2007). And it can efficiently inhibit the growth of weeds, promote the plants growth, and increased the yields and quality of crops (Mahmood et al., 2002; Sarker et al., 2003; Aniekwe et al., 2004; Bukun et al., 2005; Bhadauria \& Kumar, 2006; Islam et al., 2007; Novak et al., 2007; Liu et al., 2009). So film mulching plays an important role in crop production, especially the arid and semi-arid crops (Zhang et al., 2007; Chakraborty et al., 2008; Wang et al., 2009; Zhang et al., 2010). But, there were also some reports indicated that film mulching had some drawbacks, such as speeding up the senescence of plants and depletion of soil nutrition (Wang et al., 2004; Zhai et al., 2008; Zhang et al., 2008).

Previous studies on pineapple plants indicated that film mulching could improve the soil ecological condition and promote the growth of pineapple plants. Liu et al. (2010) reported that film mulching could availably 
maintain water content of soil of pineapple orchard, and improve the ecological condition of soil near the pineapple roots. Film mulching could increase the water content and the organic matters in the soil, and increase the number of microorganism and enzyme activities of soil such as urease, acid phosphatase, catalase in autumn and winter. Liu et al. (2008) also reported that film mulching could increase some physiological properties, such as contents of chlorophyll, content of soluble sugar and protein of pineapple leaves and roots. However, the previous studies have neglected to investigate the effects of film mulching on the quality especially on fragrance of pineapple fruits. And few investigations have been focused on the effects of film mulching on aroma components of other fruits in previous reports. So in this study, we aim to test the aroma components of pineapple fruits affectted by film mulching.

\section{Materials and Methods}

\subsection{Materials}

In this study, the materials, pineapple cultivar 'Yueyinaoka' were growing in a commercial orchard located in zengcheng city $\left(13^{\circ} 29^{\prime} 4 " \mathrm{E} \sim 113^{\circ} 59^{\prime} 44^{\prime \prime} \mathrm{E}, 23^{\circ} 4^{\prime} 42^{\prime \prime} \mathrm{N} \sim 23^{\circ} 37^{\prime} 20^{\prime \prime N}\right)$ Guangzhou, Guangdong, China. The study was designed with two treatments. One was black film mulching, and another was open field (control). Each treatment has area of about $200 \mathrm{~m}^{2}(2 \mathrm{~m} \times 100 \mathrm{~m})$. The pineapple plants were cultivated with planting density of 37500 plants/ha. The fertilizer managements for treatment and control plants were alike. The pineapple plants were induced for flowers with ethylene $(500 \times)$. The sample fruits were harvested twice, on December 15, 2009 (winter) and August 31, 2010 (summer), respectively. The sample fruits harvested in winter were induced with ethylene for flowers in Jun. 2009, and those harvested in summer were induced in Mar. 2010. Each time, 3 fruits of treatment and control were harvested randomly from the treatment and control area, respectively. All the sample fruits for detection were sent to lab immediately after harvest.

\subsection{Methods}

Aroma components were analyzed by SPME/GC-MS. Two hundred and fifty grams of fresh pulp from the 3 fruits, after being grinded evenly, were removed into a $500 \mathrm{~mL}$ headspace vial. After sealing the vial, the pulp was extracted for $30 \mathrm{~min}$ using a solid-phase micro-extraction fiber (CAR/PDMS $75 \mu \mathrm{m})$. And then desorption for $3 \mathrm{~min}$ at $220{ }^{\circ} \mathrm{C}$ and sampling.

\subsection{GC-MS conditions}

Aroma components were analyzed with Trace GC-MS analysis made by Finnigan. The MS apparatus was equipped with HP-1 column (Length $30 \mathrm{~m}$, Diameter $0.25 \mathrm{~mm}$, Film thickness $0.1 \mu \mathrm{m}$ ). Column temperature maintained at $45{ }^{\circ} \mathrm{C}$ for $1.0 \mathrm{~min}$. After that, the temperature was increased to $100{ }^{\circ} \mathrm{C}$ at a rate of $3{ }^{\circ} \mathrm{C} \cdot \mathrm{min}^{-1}$, then to $180^{\circ} \mathrm{C}$ at a rate of $10{ }^{\circ} \mathrm{C} \cdot \mathrm{min}^{-1}$. At last, the column temperature was maintained at the final temperature for 5 $\min$. He $\left(99.99 \%, 1.0 \mathrm{~mL} \cdot \mathrm{min}^{-1}\right)$ was used as the carrier gas. The MS was operated with an EI ion source with temperature of $170{ }^{\circ} \mathrm{C}$, electron energy $70 \mathrm{eV}$, and photomultiplier tube voltage of $350 \mathrm{~V}$. Mass scanning range was $35 \sim 335 \mathrm{amu}$.

Aroma components were tentatively identified by comparing their mass spectrum with the mass spectra of NIST library. The relative content of each component was determined by their peak area.

\section{Results and Discussion}

\subsection{Total ionic chromatogram of aroma components of pineapple fruits of treatment and control}

The GC-MS total ionic chromatograms of aroma components of treatment and control fruits were presented in Fig. 1 and Fig. 2. The aroma components were ascertained by searching NIST, and the relative contents were counted based on the apex area.

\subsection{Effects of film mulching on aroma components of pineapple fruits}

In this present study, besides one kind of heterocycle was detected in the treatment fruits harvested in winter, esters and alkenes were the main aroma components of pineapple fruits harvested in both winter and summer (Table 1), which agreed with previous reports (Preston et al., 2003; Elss et al., 2005).

In this trail, there were 25 kinds of aroma components, including 12 esters, 12 alkenes and 1 heterocycle detected in the treatment fruits harvested in winter with total relative content of $88.79 \%, 6.55 \%$ and $0.23 \%$ (Table 2). In the 12 kinds of esters, the predominant were hexanoic acid, methyl ester, butanoic acid, methyl ester, and octanoic acid, methyl ester with relative contents of $66.25 \%, 7.51 \%$ and $6.75 \%$, respectively. In the 12 kinds of alkenes, the predominant were 1,4-cycloheptadiene,6-(1-butenyl)-, [S-(Z)], aromadendrene, and à-copaene with relative contents of $1.89 \%, 1.05 \%$ and $1.03 \%$, respectively. There were 22 kinds of aroma components including 10 esters and 12 alkenes detected in the control fruits harvested in winter with total relative content of $87.58 \%$ and $7.76 \%$ (Table 2). In the 10 kinds of esters, the predominant were hexanoic acid, methyl ester $(71.28 \%$ ), octanoic acid, methyl ester (6.89\%), and butanoic acid, methyl ester (3.47\%). In the 12 kinds of alkenes, the 
predominant were 1,4-cycloheptadiene,6-(1-butenyl)-, [S-(Z)], à-copaene, and aromadendrene with relative contents of $2.67 \%, 1.08 \%$ and $0.94 \%$, respectively.

There were 28 kinds of aroma components, including 12 esters and 16 alkenes detected in the treatment fruits harvested in summer with total relative content of $78.56 \%$ and $19.49 \%$ (Table 2). In the 12 kinds of esters, the predominant were hexanoic acid, methyl ester (30.65\%), hexanoic acid, ethyl ester (17.50\%), and butanoic acid, 2-methyl-, methyl ester $(6.61 \%)$. In the 16 kinds of alkenes, the predominant were 1,3,7-octatriene, 3,7-dimethyl $(9.24 \%)$, aristolen $(3.86 \%)$, and à-copaene $(1.76 \%)$. There were 32 kinds of aroma components, including 9 esters and 23 alkenes detected in the control fruits harvested in summer with total relative content of $46.93 \%$ and $49.35 \%$ (Table 2). In the 9 kinds of esters, the predominant were hexanoic acid, methyl ester (28.89\%), octanoic acid, methyl ester (7.03\%), and butanoic acid, 2-methyl-, methyl ester (3.02\%). In the 23 kinds of alkenes, the predominant were 1,3,7-octatriene, 3,7-dimethyl (23.14\%), Aristolen (7.86\%), and à-copaene (3.87\%).

Previous researches indicated that film mulching can increase the fruit quality (Tachibana et al., 2009). Singh et al. (2007) reported that film mulching increased TSS content, acidity and ascorbic acid content of strawberry fruits. And also, Loughrin \& Kasperbauer (2003) reported that film mulching increased the aroma compound concentration of fresh basil leaves, and for most aroma compounds, the highest concentrations were obtained from the leaves grown over black film. In this present study, the results indicated that there were more ester and fewer alkene components detected in the treatment fruits than control. Also film mulching treatment increased the total relative content of ester components and decreased the alkene components of pineapple fruits harvested in both winter and summer.

Preston et al.(2003) reported that the esters containing sulfur such as propanoic acid, 3-(methylthio)-, methyl ester and 3-(methylthio) propanoic acid ethyl ester were the characteristic aroma components of pineapple fruits. In this study, there was one ester containing sulfur, propanoic acid, 3-(methylthio)-, methyl ester with relative content of $1.40 \%$, detected in the film mulching fruits harvested in winter, and no ester containing sulfur was detected in the control fruits harvested in winter. In the film mulching treatment fruits harvested in summer, two esters containing sulfur, propanoic acid, 3-(methylthio)-, methyl ester (2.60\%) and 3-(methylthio) propanoic acid ethyl ester (1.46\%) were detected. There was only one ester containing sulfur, propanoic acid, 3-(methylthio)-, methyl ester (3.01\%) was detected in the control fruits harvested in summer. From the above, this present study indicated that film mulching treatment increased the relative contents of characteristic aroma components of pineapple fruits.

\section{Conclusion}

In this study, esters and alkenes were the main aroma components of pineapple fruits. Film mulching treatment increased the number of ester aroma components of pineapple fruits harvested in winter and summer, and decreased the number of alkene aroma components harvested in summer. Film mulching increased the total relative content of ester components and decreased the alkene components of pineapple fruits harvested in winter and summer. Also film mulching increased the characteristic aroma components of pineapple fruits harvested in winter and summer.

\section{Acknowledgement}

This study was financially supported by the pineapple industry project (3-41) from Ministry of Agriculture of P. R. China.

\section{References}

Aniekwe N L, Okereke O U, Anikwe. M A N. (2004). Modulating effect of black plastic mulch on the environment, growth and yield of cassava in a derived savanna belt of nigeria. Tropicultura, 22(4), 185-190.

Bhadauria H S \& Kumar V. (2006). Effect of mulching on growth and productivity of Okra (Abelmoschus esculentus. L. ) Moench under saline irrigation condition. American Journal of Plant Physiology, 1(2), 214-216. doi:10.3923/ajpp.2006.214.216, http://dx.doi.org/10.3923/ajpp.2006.214.216

Bu Y S, Miao G Y, Zhou N J, Shao H L \& Wang J C. (2006). Analysis and comparison of the effects of plastic film mulching and straw mulching on soil fertility. Scientia Agricultura Sinica, 39(5), 1069-1075.

Bukun B, Gercek S, Boydak E \& Dikilitas M. (2005). A novel irrigation system (water pillow) with mulching effect for the control of weeds in soybean plants in arid and semi-arid regions. Pakistan Journal of Biological Sciences, 8(5), 730-733. doi:10.3923/pjbs.2005.730.733, http://dx.doi.org/10.3923/pjbs.2005.730.733

Chakraborty D, Nagarajan S, Aggarwal P, Gupta V K, Tomar R K, Garg R N, Sahoo R N, Sarkar A, Chopra U K, Sundara Sarma K S \& Kalra N. (2008). Effect of mulching on soil and plant water status, and the growth and yield of wheat (Triticum aestivum L.) in a semi-arid environment. Agricultural water management, 95, 1323-1334. doi:10.1016/j.agwat.2008.06.001, http://dx.doi.org/10.1016/j.agwat.2008.06.001

Elss S, Preston C, Hertzig C, Heckel F, Richling E \& Schreier P. (2005). Aroma profiles of pineapple fruit 
(Ananas comosus [L.] Merr.) and pineapple products . LWT-Food Science and Technology, 38(3), $263-274$. doi:10.1016/j.lwt.2004.07.014, http://dx.doi.org/10.1016/j.lwt.2004.07.014

Islam M J, Hossain A K M M, Khanam F, Majumder U K, Rahman M M \& Rahman S M. (2007). Effects of mulching and fertilizer on growth and yield of garlic at Dinajpur in Bangladesh. Asian Journal of Plant Science, 6(1). 98-101. doi:10.3923/ajps.2007.98.101, http://dx.doi.org/10.3923/ajps.2007.98.101

Li Y S, Wu L H, Zhao L M, Lu X H, Fan Q L \& Zhang F S. (2007). Influence of continuous plastic film mulching on yield, water use efficiency and soil properties of rice fields under non-flooding condition. Soil $\&$ Tillage Research, 93, 370-378. doi:10.1016/j.still.2006.05.010, http://dx.doi.org/10.1016/j.still.2006.05.010

Liu C A, Jin S L, Zhou L M, Jia Y, Li F M, Xiong Y C \& Li X G. (2009). Effects of plastic film mulch and tillage on maize productivity and soil parameters. European Journal of Agronomy, 31, $241-249$. doi:10.1016/j.eja.2009.08.004, http://dx.doi.org/10.1016/j.eja.2009.08.004

Liu C H, Liu Y, Yi G J, Liao M J, Wei F L, Zhu S Q \& Wu Y Z. (2010). Effects of film mulching on vegetative growth of pineapple and soil physicochemical properties. Chinese Journal of Soil Science, 41(5), 1105-1109.

Liu C H, Liu Y, Yi G J, Zhong Y \& Jiang B. (2008). Effects of plastic film mulching on several physiological indexes of pineapple plants. Chinese Journal of Tropical Crops, 29(5), 546-550.

Loughrin J H \& Kasperbauer M J. (2003). Aroma content of fresh basil (Ocimum basilicum L.) leaves is affected by light reflected from colored mulches. Journal of Agriculture and Food Chemistry, 51, 2272-2276. doi:10.1021/jf021076c, http://dx.doi.org/10.1021/jf021076c

Mahmood M. M, Farooq K, Hussain A \& Sher R. (2002). Effects of mulching on growth and yield of potato crop. Asian Journal of Plant Science, 1(2), 132-133. doi:10.3923/ajps.2002.132.133, http://dx.doi.org/10.3923/ajps.2002.132.133

Novak B, Žutić I, Toth N \& Dobričević N. (2007). Sweet potato [Ipomoea batatas (L.) Lam] yield influenced by seedlings and mulching. Agriculturae Conspectus Scientificus, 72 (4), 357-359.

Preston C, Riching E, Elss S, Appel M, Heckel F, Hartlieb A \& Schreier P. (2003). On-line gas chromatography combustion/pyrolysis isotope ratiomass spectrometry (HRGC-C/P-IRMS) of pineapple (Ananas comosus L.Merr.) volatiles. Journal of Agricultural and Food Chemistry, 51(27), 8027-8031. doi:10.1021/jf030540q, http://dx.doi.org/10.1021/jf030540q

Sarker M Y, Begum F, Hasan M K, Raquibullah S M \& Kader M A. (2003). Effect of different sources of nutrients and mulching on growth and yield contributing to characters of cabbage. Asian Journal of Plant Science, 2(2), 175-179. doi:10.3923/ajps.2003.175.179, http://dx.doi.org/10.3923/ajps.2003.175.179

Singh R, Sharma R R \& Goyal R K. (2007). Interactive effects of planting time and mulching on 'Chandler' strawberry (Fragaria ananassa Duch.). Scientia Horticulturae, 111, 344-351. doi:10.1016/j.scienta.2006.11.002, http://dx.doi.org/10.1016/j.scienta.2006.11.002

Tachibana Y, Maeda T, Ito O, Maeda Y \& Kunioka M. (2009). Utilization of a biodegradable mulch sheet produced from poly(lactic acid)/ecoflex $\AA /$ modified starch in mandarin orange groves. International Journal of Molecular Sciences, 10, 3599-3615. doi:10.3390/ijms10083599, http://dx.doi.org/10.3390/ijms10083599

Tarara J M. (2000). Microclimate modification with plastic mulch. Hortscience, 35(2), 169-180.

Wang Y J, Xie Z K, Malhi S S, Vera C L, Zhang Y B \& Wang J N. (2009). Effects of rainfall harvesting and mulching technologies on water use efficiency and crop yield in the semi-arid Loess Plateau, China. Agricultural water management, 96, 374-382. doi:10.1016/j.agwat.2008.09.012, http://dx.doi.org/10.1016/j.agwat.2008.09.012

Wang Y Z, Liu R T \& Zhang J G. (2004). On physiological mechanism of early aging caused by plastic mulching on tomatoes. Journal of Shanxi Agriculture University, 24(1), 60-62.

Zhai S, Liang Y L, Zhang X S, Wang J Y, Dai Q H \& Liu H. (2008). Effects of soil mulching on cucumber quality, water use efficiency and soil environment in greenhouse. Transactions of the CSAE, 24(3), 65-71.

Zhang G S, Chan K Y, Li G D \& Huang G B. (2008). Effect of straw and plastic film management under contrasting tillage practices on the physical properties of an erodible loess soil. Soil \& Tillage Research, 98, 113-119. doi:10.1016/j.still.2007.09.001, http://dx.doi.org/10.1016/j.still.2007.09.001

Zhang J, Ren X L, Luo S F, Hai J B \& Jia Z K. (2010). Influences of different covering materials mulching on soil moisture and corn yield. Transactions of the CSAE, 26(6), 14-19.

Zhang S L, Lo“vdahl L, Grip H, Jansson P E \& Tong Y A. (2007). Modelling the effects of mulching and fallow cropping on water balance in the Chinese Loess Plateau. Soil \& Tillage Research, 93, $283-298$. doi:10.1016/j.still.2006.05.002, http://dx.doi.org/10.1016/j.still.2006.05.002 
Table 1. Aroma components and relative contents of treatment and control pineapple fruits harvested in winter and summer

\begin{tabular}{|c|c|c|c|c|c|c|}
\hline \multirow{2}{*}{$\begin{array}{l}\text { Catego } \\
\text { ries }\end{array}$} & \multirow{2}{*}{ Component name } & \multirow{2}{*}{$\begin{array}{l}\text { Molecular } \\
\text { formula }\end{array}$} & \multicolumn{2}{|c|}{ Harvested in winter } & \multicolumn{2}{|c|}{ Harvested in summer } \\
\hline & & & Treatment & Control & Treatment & Control \\
\hline \multirow[t]{17}{*}{ Ester } & Butanoic acid, methyl ester & $\mathrm{C}_{5} \mathrm{H}_{10} \mathrm{O}_{2}$ & 7.51 & 3.47 & 3.29 & 1.31 \\
\hline & Butanoic acid, 2-methyl-, methyl ester & $\mathrm{C}_{6} \mathrm{H}_{12} \mathrm{O}_{2}$ & 1.87 & 0.35 & 6.61 & 3.02 \\
\hline & Butanoic acid,ethyl ester & $\mathrm{C}_{6} \mathrm{H}_{12} \mathrm{O}_{2}$ & 0.11 & - & 0.49 & - \\
\hline & Butanoic acid, 2-methyl-, ethyl ester & $\mathrm{C}_{7} \mathrm{H}_{14} \mathrm{O}_{2}$ & - & - & 4.67 & - \\
\hline & Pentanoic acid, methyl ester & $\mathrm{C}_{6} \mathrm{H}_{12} \mathrm{O}_{2}$ & 0.84 & 0.47 & - & - \\
\hline & Hexanoic acid, methyl ester & $\mathrm{C}_{7} \mathrm{H}_{14} \mathrm{O}_{2}$ & 66.25 & 71.28 & 30.65 & 28.89 \\
\hline & 3-hexenoic acid, methyl ester, (Z)- & $\mathrm{C}_{7} \mathrm{H}_{12} \mathrm{O}_{2}$ & 0.23 & 0.22 & - & - \\
\hline & Hexanoic acid, ethyl ester & $\mathrm{C}_{8} \mathrm{H}_{16} \mathrm{O}_{2}$ & 2.81 & 2.51 & 17.50 & 1.76 \\
\hline & Propanoic acid, 3-(methylthio)-, methyl ester & $\mathrm{C}_{5} \mathrm{H}_{10} \mathrm{O}_{2} \mathrm{~S}$ & 1.40 & - & 2.60 & 3.01 \\
\hline & 3-(Methylthio) propanoic acid ethyl ester & $\mathrm{C}_{6} \mathrm{H}_{12} \mathrm{O}_{2} \mathrm{~S}$ & - & - & 1.46 & - \\
\hline & Heptanoic acid, methyl ester & $\mathrm{C}_{8} \mathrm{H}_{16} \mathrm{O}_{2}$ & - & 1.41 & - & - \\
\hline & 4-octenoic acid, methyl ester, (Z)- & $\mathrm{C}_{9} \mathrm{H}_{16} \mathrm{O}_{2}$ & - & 0.81 & - & - \\
\hline & Octanoic acid, methyl ester & $\mathrm{C}_{9} \mathrm{H}_{18} \mathrm{O}_{2}$ & 6.75 & 6.89 & 4.92 & 7.03 \\
\hline & 4-octenoic acid, methyl ester & $\mathrm{C}_{9} \mathrm{H}_{16} \mathrm{O}_{2}$ & 0.38 & - & 1.87 & 1.25 \\
\hline & 4-octenoic acid, ethyl ester & $\mathrm{C}_{10} \mathrm{H}_{18} \mathrm{O}_{2}$ & - & - & 1.12 & - \\
\hline & Octanoic acid,ethyl ester & $\mathrm{C}_{10} \mathrm{H}_{20} \mathrm{O}_{2}$ & 0.21 & 0.17 & 2.97 & 0.44 \\
\hline & Methyl 3-acetoxyhexanoate & $\mathrm{C}_{9} \mathrm{H}_{16} \mathrm{O}_{4}$ & 0.43 & - & - & 0.22 \\
\hline \multirow[t]{31}{*}{ Alkene } & 1,3,6-octatriene,3,7-dimethyl-,(E) & $\mathrm{C}_{10} \mathrm{H}_{16}$ & 0.37 & 0.39 & 0.75 & 1.44 \\
\hline & 1,3,7-octatriene, 3,7-dimethyl- & $\mathrm{C}_{10} \mathrm{H}_{16}$ & - & - & 9.24 & 23.14 \\
\hline & DL-limonene & $\mathrm{C}_{10} \mathrm{H}_{16}$ & 0.26 & 0.37 & - & - \\
\hline & à-myrcene & $\mathrm{C}_{10} \mathrm{H}_{16}$ & 0.19 & - & 0.23 & 0.2 \\
\hline & 1,3,6-octatriene,3,7-dimethyl-,(E) & $\mathrm{C}_{10} \mathrm{H}_{16}$ & 0.83 & 0.72 & - & - \\
\hline & 2,4,6-octatriene,2,6-dimethyl- & $\mathrm{C}_{10} \mathrm{H}_{16}$ & - & - & 0.57 & 1.04 \\
\hline & Alloocimene & $\mathrm{C}_{10} \mathrm{H}_{16}$ & - & - & - & 1.03 \\
\hline & 1,4-cycloheptadiene,6-(1-butenyl)-, [S-(Z)]- & $\mathrm{C}_{11} \mathrm{H}_{16}$ & 1.89 & 2.67 & - & - \\
\hline & $1,3,5,8$-bndecatetraene & $\mathrm{C}_{11} \mathrm{H}_{16}$ & 0.14 & 0.16 & - & 2.72 \\
\hline & 6-[(Z)-1-butenyl]-1,4-cycloheptadiene & $\mathrm{C}_{11} \mathrm{H}_{16}$ & - & - & - & 0.25 \\
\hline & (3Z,5E)-1,3,5-Undecatriene & $\mathrm{C}_{11} \mathrm{H}_{18}$ & 0.10 & 0.12 & - & - \\
\hline & (E,E)-1,3,5-Undecatriene & $\mathrm{C}_{11} \mathrm{H}_{18}$ & - & - & - & 0.25 \\
\hline & 6-butyl-1,4-cycloheptadiene & $\mathrm{C}_{11} \mathrm{H}_{18}$ & - & - & - & 0.18 \\
\hline & Aromadendrene & $\mathrm{C}_{15} \mathrm{H}_{24}$ & 1.05 & 0.94 & - & - \\
\hline & Aristolen & $\mathrm{C}_{15} \mathrm{H}_{24}$ & 0.15 & - & 3.86 & 7.86 \\
\hline & à-copaene & $\mathrm{C}_{15} \mathrm{H}_{24}$ & 1.03 & 1.08 & 1.76 & 3.87 \\
\hline & à-amorphene & $\mathrm{C}_{15} \mathrm{H}_{24}$ & 0.15 & - & - & - \\
\hline & à-gurjunene & $\mathrm{C}_{15} \mathrm{H}_{24}$ & 0.39 & 0.12 & 0.50 & 1.78 \\
\hline & Sativen, $(+)-$ & $\mathrm{C}_{15} \mathrm{H}_{24}$ & - & 0.11 & 0.14 & 0.83 \\
\hline & $(+)$-cycloisosativene & $\mathrm{C}_{15} \mathrm{H}_{24}$ & - & 0.16 & 0.32 & 0.36 \\
\hline & à-muurolene & $\mathrm{C}_{15} \mathrm{H}_{24}$ & - & 0.92 & 0.49 & 1.47 \\
\hline & Humuleo-(vl) & $\mathrm{C}_{15} \mathrm{H}_{24}$ & - & - & 0.47 & \\
\hline & à-elemene & $\mathrm{C}_{15} \mathrm{H}_{24}$ & - & - & 0.32 & 0.52 \\
\hline & Germacrene-D & $\mathrm{C}_{15} \mathrm{H}_{24}$ & - & - & 0.13 & 0.2 \\
\hline & $\begin{array}{l}\text { Spiro[5.5]undec-2-ene,3,7,7-trimethyl-11-methylene-, } \\
(-)\end{array}$ & $\mathrm{C}_{15} \mathrm{H}_{24}$ & - & - & 0.15 & 0.15 \\
\hline & $\begin{array}{l}\text { Naphthalene,1,2,3,4,4a,5,6,8a-octahydro-7-methyl-4- } \\
\text { methylene-1-(1-methylethyl)-,(1à,4Aà,8A) }\end{array}$ & $\mathrm{C}_{15} \mathrm{H}_{24}$ & - & - & 0.32 & - \\
\hline & Delta.-cadinene & $\mathrm{C}_{15} \mathrm{H}_{24}$ & - & - & 0.24 & 0.32 \\
\hline & $\begin{array}{l}\text { Cycloheptane,4-methylene-1-methyl-2-(2-methyl-1-pr } \\
\text { open-1-yl)-1-vinyl- }\end{array}$ & $\mathrm{C}_{15} \mathrm{H}_{24}$ & - & - & - & 0.1 \\
\hline & Valencene & $\mathrm{C}_{15} \mathrm{H}_{24}$ & - & - & - & 1.28 \\
\hline & $\{-\}$-isoledene & $\mathrm{C}_{15} \mathrm{H}_{24}$ & - & - & - & 0.15 \\
\hline & 1,3,6,10-dodecatriene,3,7,11-trimethyl-,(Z,E)- & $\mathrm{C}_{15} \mathrm{H}_{24}$ & - & - & - & 0.21 \\
\hline $\begin{array}{l}\text { Heteroc } \\
\text {-ycle }\end{array}$ & 5,6-dihydro-5,6-dimethylbenzo[C]cinnoline & $\mathrm{C}_{14} \mathrm{H}_{14} \mathrm{~N}_{2}$ & 0.23 & - & - & - \\
\hline
\end{tabular}

Note: - not found or not exist 
Table 2. Aromatic categories and relative contents of film mulching treatment and control pineapple fruits harvested in winter and summer

\begin{tabular}{|c|c|c|c|c|c|c|c|c|}
\hline \multirow{3}{*}{$\begin{array}{l}\text { Aroma } \\
\text { component } \\
\text { Categories }\end{array}$} & \multicolumn{4}{|c|}{ Relative content $(\%)$} & \multicolumn{4}{|c|}{ The number of aroma components } \\
\hline & \multicolumn{2}{|c|}{ Harvested in winter } & \multicolumn{2}{|c|}{ Harvested in summer } & \multicolumn{2}{|c|}{ Harvested in winter } & \multicolumn{2}{|c|}{ Harvested in summer } \\
\hline & Treatment & Control & Treatment & Control & Treatment & Control & Treatment & Control \\
\hline Ester & 88.79 & 87.58 & 78.56 & 46.93 & 12 & 10 & 12 & 9 \\
\hline Alkene & 6.55 & 7.76 & 19.49 & 49.35 & 12 & 12 & 16 & 23 \\
\hline Heterocycle & 0.23 & - & - & - & 1 & - & - & - \\
\hline Total & 95.57 & 95.34 & 98.05 & 96.28 & 25 & 22 & 28 & 32 \\
\hline
\end{tabular}

Note: — not found or not exist
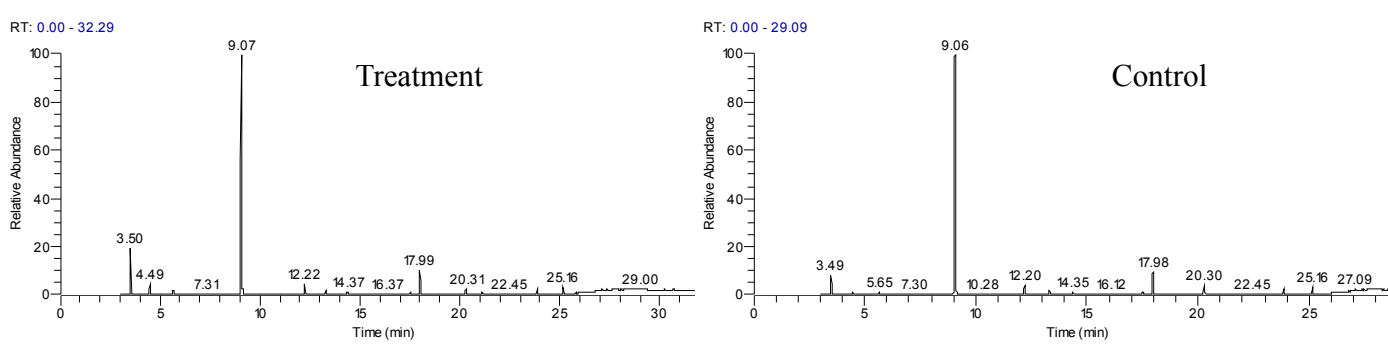

Time (min)

Figure 1. Total GC-MS ionic chromatogram of aroma components of treatment and control fruits harvested in winter
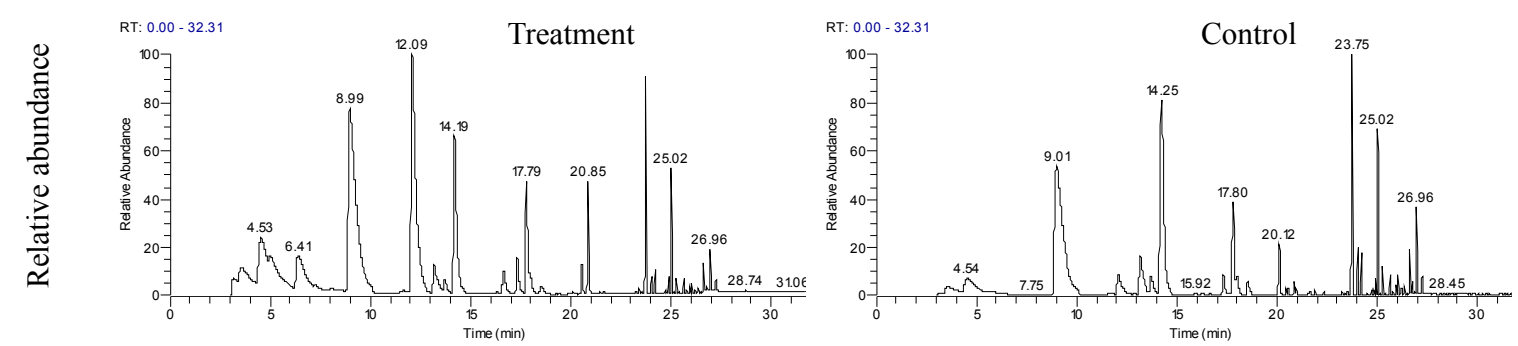

Time (min)

Figure 2. Total GC-MS ionic chromatogram of aroma components of treatment and control fruits harvested in summer 